\title{
Pediatric Facial Fractures: Update on Their Treatment
}

\author{
Igor Figueiredo Pereira* \\ Department of Prosthodontics and Bucco Facial Surgery, University of Pernambuco, Brazil
}

*Corresponding author: Igor F Pereira, Department of Prosthodontics and Bucco Facial Surgery, University of Pernambuco, Av. Gal. Newton Cavalcanti, 1650, Tabatinga, Camaragibe, PE, 54756-220, Brazil

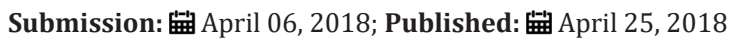

\section{Introduction}

Face fractures in children are relatively rare and evaluated separately because of their particular aspects of diagnosis and treatment. This is because, in children, the bones present greater elasticity, small pneumatization of the sinuses, greater thickness of the surrounding adipose tissue, and good stability of the maxilla and mandible due to the presence of unerupted teeth [1]. These characteristics make it take a lot of energy to cause a fracture in developing bones [2]. The incidence of facial fractures in children and adolescents group is approximately $10 \%$. The majority of fractures occur over 5 years of age, with peaks of incidence at school age and adolescence, when the characteristics of craniofacial traumas are similar to those of the adult population [3].

Social, cultural and environmental aspects are responsible for changing the epidemiology of craniofacial trauma. The incidence of face fractures in the pediatric population is higher in boys at almost all ages, ranging up to the ratio of $2: 1$ [4].

With regard to etiology, the causes are similar to those of face fractures in adults. Children under 6 years of age usually suffer from low energy traumas, such as falls, causing minor fractures [5]. Larger children often suffer from more severe trauma, such as those caused by motor vehicle accidents and sports activities. Automobile accident traumas are the leading cause of death in adolescents period. Associated lesions are common, occurring in $25-75 \%$ of cases and include cranioencephalic trauma, upper and lower limb fractures, abdominal, thoracic and soft tissue trauma [6].

\section{Treatment}

Initial attention should be given to soft parts and noble structures such as the eyeball, facial nerve, salivary glands and their ducts. The wounds should be cleaned, debrided and sutured, if necessary, so that within 48 to 72 hours, we have an optimal field of fracture access [7].

The treatment of facial fractures in pediatric patients is still controversial, but it is a consensus in the literature that changes in growth should be prevented, seeking a more conservative treatment whenever indicated. Currently, more precise and primary surgical techniques, associated with a stable fixation of facial fractures have already been successfully applied. When surgery is required, the procedure should be less invasive, using more delicate fixation devices. In addition, considering that bone remodeling is rapid in the child, any intervention should be performed as early as possible [8].

The treatment is mainly aimed at maintaining the patient's function and aesthetics, preventing asymmetries and avoiding changes in bone growth. Fractures without displacement or malocclusion are better treated with observation, restriction of diet, rest and analgesia; however, significantly displaced or comminuted fractures can cause functional damage, aesthetic deformity or both. Therefore they have indication of surgical intervention. Multiple fractures produce a more unstable injury pattern than isolated fractures. Thus, there is also an indication of open reduction and internal fixation [6].

Several factors should be considered in the treatment of facial fractures in children. Among these factors, the age of the patient, stage of bone development, deciduous, mixed or permanent dentition and degree of fracture displacement. When fixation is required, titanium miniplates are the most commonly used along with resorbable plaque systems [9].

The use of resorbable plaques has been discussed and their advantages and disadvantages can be considered during the choice of treatment proposal. As an advantage, it should be emphasized that there is no need to remove fixation material and less influence on facial growth. As a disadvantage, we can mention an important inflammatory process and a less efficient fixation when compared to other methods, in addition, the resorbable plates have a very high cost, since this system has been less and less used $[4,10]$.

The use of mini titanium plates has been very successful, when the indication and the technique are well recommended, that is, in cases of higher energy fractures with greater displacement or comminution. Patients treated with this type of fixation present a 
more effective consolidation of the fracture, however, depending on the patient's age, they should be removed in a second surgical moment, due to facial growth $[5,11]$.

\section{Conclusion}

Therefore, in recent years, non-resorbable titanium mini-plate systems, when well indicated, have been the most commonly used technique for the reduction of pediatric facial fractures.

\section{References}

1. Siy RW, Brown RH, Koshy JC, Stal S, Hollier LH(2011) General management considerations in pediatric facial fractures. J Craniomaxillofac Surg 22(4): 1190-1195.

2. Osunde OD, Amole IO, Ver-or N, Akhiwu BI, Adebola RA, et al. (2013) Pediatric maxillofacial injuries at a Nigerian teaching hospital: a threeyear review. Niger J Clin Pract 16(2): 149-154.

3. Almahdi HM, Higzi MA (2016) Maxillofacial fractures among Sudanese children at Khartoum Dental Teaching Hospital. BMC Res Notes 9: 120.

4. Li Z, David O, Li ZB (2014) The use of resorbable plates in association with dental arch stabilization in the treatment of mandibular fractures in children. J Craniomaxillofac Surg 42(5): 548-551.
5. Ferreira P, Barbosa J, Amarante J, Insua-Pereira I, Soares C, et al. (2015) Changes in the characteristics of facial fractures in children and adolescents in Portugal 1993-2012. Br J Oral Maxillofac Surg 53(3): 251256.

6. Macmillan A, Lopez J, Luck JD, Faateh M, Manson P, et al. (2017) How do le fort-type fractures present in a pediatric cohort? J Oral Maxillofac Surg 17(12): 31459-31463.

7. Smith DM, Bykowski MR, Cray JJ, Naran S, Rottgers SA, et al. (2013) 215 mandible fractures in 120 children: demographics, treatment, outcomes, and early growth data. Plast Reconst Surg 131(6): 1348-1358.

8. Goth S, Sawatari Y, Peleg M (2012) Management of pediatric mandible fractures. J Craniomaxillofac Surg 23(1): 47-56.

9. Bobrowski AN, Torriani MA, Sonego CL, Carvalho PHD, Post LK, et al. (2017) Complications associated with the treatment of fractures of the dentate portion of the mandible in paediatric patients: a systematic review. Int J Oral Maxillofac Surg 46(4): 465-472.

10. Yang L, Xu M, Jin X, Xu J, Lu J, et al. (2013) Complications of absorbable fixation in maxillofacial surgery: a meta-analysis. PLoS One 8(6): e67449.

11. Rottgers SA, Decesare G, Chao M, Smith DM, Cray JJ, et al. (2011) Outcomes in pediatric facial fractures: early follow-up in 177 children and classification scheme. J Craniofac Surg 22(4): 1260-1265.
Creative Commons Attribution 4.0 International License

For possible submissions Click Here

\section{Submit Article}

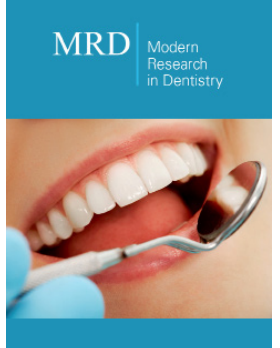

\section{Modern Research in Dentistry}

\section{Benefits of Publishing with us}

- High-level peer review and editorial services

- Freely accessible online immediately upon publication

- Authors retain the copyright to their work

- Licensing it under a Creative Commons license

- Visibility through different online platforms 